\title{
A SOLIDARIEDADE SOCIAL MERITÓRIA E A CONCESSÃO DAS PENSÕES ESPECIAIS PREMIAIS NO BRASIL
}

Milton Vasques Thibau de Almeida

Doutor em Direito pela UFMG e Professor do Curso de Mestrado em Direito da Universidade de Itaúna, na linha de pesquisa "Constitucionalismo Social: Fundamentos, Políticas Públicas e Privadas de Proteção Social Nacional, Comunitária e Internacional".

\section{Resumo}

A constituição brasileira contempla diversos tipos de solidariedade, sendo algumas de forma expressa e outras de forma implícita, merecendo destaque, no presente artigo, a solidariedade social meritória, que dá fundamento legal às concessóes das pensões especiais mensais e vitalícias dos ex-jogadores de futebol da Seleção Brasileira campeã dos Mundiais de 1958, 1962 e 1970, bem como à ex-atleta olímpica Laís da Silva Souza. A jurisprudência constitucional brasileira reconheceu a constitucionalidade das leis que concederam tais pensóes premiais, mas lhes atribuiu a natureza jurídica de benefício assistencialista. Contudo, uma análise meticulosa das leis que concederam essas pensóes premiais revela a existência de pressupostos e de requisitos que são típicos de uma natureza previdenciária.

\section{Palavras-chave}

Pensão especial; Aposentadoria premial; Solidariedade; Solidariedade social meritória.

\section{Abstract}

The Brazilian constitution contempt any different types of solidarity, some of them by the expressed form and others by the implicit form, have being awarded in this article the honor social solidarity, that gives legal fundaments to the special monthly and for all life pensions concessions to the ex-football players of the champion Brazilian Team on the World Championships of 1958, 1962 and 1970, the same that has been occurred with the ex-olimpic athletic Laís da Silva Souza. The Brazilian constitutional jurisprudence has been recognized the constitutionality of those laws that has given those rewarded pension concessions, but has been given to them the juridical nature of assistance benefit. 
Although a particular analyses of these laws that has been given those reward pensions concession revels the existence of supposes and requires that has been typical of the pension funds juridical nature.

\section{Key words}

Special pension; Reward retirement; Solidarity; Honor social solidarity.

\section{Introdução}

Duas leis recentemente publicadas no Brasil colocaram em evidência uma prática administrativa de concessão de benefícios não-contributivos pela União, em caráter vitalício e premial, aos ex-jogadores de futebol das Seleçôes Brasileiras de futebol campeãs das Copas do Mundo de 1958, 1962 e 1970 (Lei no 12.663, de 05/06/2012), e à ex-atleta da Seleção Brasileira olímpica de ginástica Laís da Silva Souza (Lei no 13.087, de 12/01/2015), que se acidentou no dia 21/01/2014, em Salt Lake City, nos Estados Unidos da América, durante o intervalo de lazer, quando praticava esqui nas montanhas nevadas.

A concessão desses benefícios mensais vitalícios não-contributivos pelas mencionadas Lei no 12.663, de 05/06/2012, e Lei no 13.087 , de 12/01/2015, reaviva, no Brasil, o debate sobre o fundamento e a natureza jurídica desses benefícios, que foram tidos pela jurisprudência constitucional, no primeiro caso, como sendo de natureza assistencialista.

Examinamos, pois, a concessão dessas rendas mensais vitalícias não-contributivas à luz dos preceitos constitucionais e da jurisprudência constitucional produzida pelo Excelso Supremo Tribunal Federal, com visos a desvendar o fundamento e a natureza jurídica dessas concessões.

\section{A Constitucionalidade das Rendas Mensais Vitalícias Não-Contributivas na Jurisprudência Constitucional}

A constitucionalidade da Lei no 13.087, de 12/01/2015, parece ser inquestionável, à primeira vista, pois o Plenário do Excelso Supremo Tribunal Federal já firmou jurisprudência, há quase um ano antes, sobre a constitucionalidade da outorga de benefícios assistencialistas pelo Poder Público, sem a necessária existência de dotação orçamentária, por ocasião do julgamento da arguição de inconstitucionalidade da Lei Geral da Copa, que concedeu pensóes não-contributivas aos atletas campeóes das Copas do Mundo de 1958, de 1962 e de 1970, no julgamento do processo de número ADI 4976, em 07/05/2014, tendo como Relator o Ministro Ricardo Lewandowski. 
Toda lei é promulgada no pressuposto de que esteja conforme a constituição, vale dizer, que seja constitucional, e, portanto, seja revestida de eficácia jurídica até que outra lei a revogue ou que tenha a sua inconstitucionalidade declarada pelo Poder Judiciário. Ser constitucional não significa estar a lei de acordo com a literalidade do texto da Constituição, mas em harmonia com os seus princípios e suas disposiçôes.

Não há qualquer princípio jurídico expresso ou qualquer disposição constitucional específica a respeito da concessão de aposentadorias ou de pensões de natureza assistencialista pelo Poder Público, o que, no entanto, não significa que estariam vedadas.

Em princípio, as aposentadorias e as pensóes devem se enquadrar nos princípios jurídicos e nas disposiçóes legais pertinentes aos regimes de previdência social, sejam as relativas ao único regime geral (RGPS) ou aquelas relativas aos milhares de regimes próprios dos servidores públicos (RPPS).

Entendemos que, no campo da proteção social, as práticas constitucionais são mais importantes do que os preceitos constitucionais, do que é exemplo a promulgação da referida Lei no 12.663, de 2012 (Lei Geral da Copa), que gerou o precedente de constitucionalidade das leis que conferem benefícios assistencialistas não contributivos, no julgamento do Excelso Supremo Tribunal Federal.

Sobressai no julgamento do caso precedente do processo ADI 4976, do Excelso Supremo Tribunal Federal, o fundamento de que o prêmio em dinheiro e o auxílio mensal concedido aos ex-jogadores campeões das Seleçôes Brasileiras de futebol das Copas do Mundo de 1958, de 1962 e de 1970, se revestem de natureza assistencialista.

\section{Questionamento sobre a Natureza Jurídica Assistencialista dos Benefícios Não-Contributivos Concedidos aos Ex-Jogadores de Futebol e à Ex-Atleta Olímpica}

Releva examinar qual seria a natureza jurídica desses benefícios não-contributivos, concedidos vitaliciamente aos ex-jogadores de futebol e à ex-atleta olímpica, a título, respectivamente, de auxílio especial mensal e de pensão especial.

A natureza jurídica desses prêmios em dinheiro e auxílios mensais concedidos pela Lei Geral da Copa seria mesmo de cunho assistencialista, como entendeu o Excelso Supremo Tribunal Federal?

O fundamento da natureza assistencialista é juridicamente defensável, mas também é questionável, por isso, de momento, o aceitamos como argumento jurídico válido para a fundamentação do acórdão proferido no processo ADI 4976, para atendimento à exigência constitucional quanto à fundamentação das decisóes judiciais pelos órgãos do Poder Judiciário, conforme exigência feita pelo artigo 93, inciso IX, da Constituição brasileira de 1988 . 
Do ponto de vista doutrinário, não podemos aceitar sem questionamento esse fundamento da natureza jurídica assistencialista, que foi atribuída pela jurisprudência constitucional aos prêmios em dinheiro e aos auxílios mensais concedidos aos ex-jogadores da Seleção Brasileira de futebol.

O fundamento utilizado no julgamento no processo judicial é plausível, mas não é contundente, e, por isso, carece de uma análise mais aprofundada. Pode ser que seja mesmo um benefício assistencialista, pode ser que não. $\mathrm{O}$ tema suscita maiores reflexôes.

Questionamos essa suprema afirmação da jurisprudência constitucional no sentido de que a natureza jurídica desses prêmios em dinheiro e auxílios mensais vitalícios seja assistencialista.

\subsection{Elementos Objetivos}

Do ponto de vista objetivo, esses benefícios concedidos em dinheiro (o prêmio em dinheiro) poderiam ser justificados como uma loteria ou uma indenização, pois as loterias constituem uma das espécies da poupança coletiva, ao passo que a indenização é a mãe dos regimes de previdência social e complementar.

A seu turno, o auxílio-mensal só poderia se revestir da natureza de renda assistencialista se os beneficiados estivessem em condição de indigência, o que não era o caso dos ex-jogadores de futebol contemplados, assim como, também, não era o caso da ex-atleta olímpica Laís da Silva Souza.

A concessão desse auxílio mensal especial ostenta elementos de caracterização de uma natureza jurídica previdenciária, porquanto: a) será administrado pelo INSS - Instituto Nacional do Seguro Social, conforme determina o artigo 44, caput, da Lei no 12.663 , de 2012, que é órgão de gestão do seguro social, como emerge de sua própria denominação; b) é direito condicional, concedido apenas a quem figurar em uma listagem (isto é, uma inscrição) que será promovida de ofício pelo Ministério do Esporte (artigo 44, parágrafo único, da mesma lei), e na qual somente poderão ser inscritos "os jogadores, titulares ou reservas das seleçôes brasileiras masculinas campeãs das copas mundiais masculinas da FIFA nos anos de 1958, 1962 e 1970" (artigo 37, caput, da lei em comento); c) do ponto de vista da cobertura, reveste-se esse auxílio mensal especial de diversas naturezas jurídicas, pois: a) pode ser uma concessão direta de aposentadoria em valor integral, se o beneficiário estiver vivo e não possuir renda; b) pode ser uma concessão direta de aposentadoria complementar, se o beneficiário estiver vivo e possuir renda inferior ao limite-teto dos benefícios do Regime Geral de Previdência Social; c) pode ser uma concessão direta de pensão em valor integral, se o beneficiário já tiver falecido e seus dependentes não tiverem renda; d) pode ser uma concessão de complementação de pensão, se o beneficiário 
já tiver falecido e seus dependentes estiverem usufruindo de pensão com valor inferior ao limite-teto dos benefícios do Regime Geral de Previdência Social.

$\mathrm{Na}$ área de ação da assistência social, a rigor jurídico, não existem benefícios, apenas a prestação de serviços, com duas exceçóes: a) a garantia da renda mensal prevista no artigo 203, inciso IV, da Constituição brasileira de 1988, no valor único de 1 (hum) salário mínimo, para as pessoas portadoras de deficiência e para os idosos desprovidos de renda e do amparo familiar; b) a bolsa família, cuja natureza jurídica é de complemento da renda mínima mensal familiar, instituída por um Programa de governo, na área de ação da assistência social.

O prêmio em dinheiro concedido aos ex-jogadores de futebol da Seleção Brasileira campeóes das Copas do Mundo de 1958, de 1962 e de 1970 possui a inescusável natureza jurídica de prêmio, tal como um prêmio de loteria, visto que as loterias são espécies do gênero poupança coletiva, distribuindo os valores arrecadados com as poucas pessoas aquinhoadas pela sorte, ao passo que a previdência social, outra espécie do mesmo gênero, distribui os valores que arrecada com um elenco maior de pessoas, que são aquinhoadas pelo azar - o azar de terem sido acometidas por um infortúnio. Como se trata de prestação única não há que se compará-la com as prestaçóes continuadas concedidas pela mesma Lei Geral da Copa, mas não deixam de se confundir com os benefícios previdenciários de prestação única, cujo valor elevado ( $\mathrm{R} \$ 100.000,00$ para cada ex-jogador), considerado o tempo decorrido desde Tri-campeonato Mundial de 1970, bem poderia ser confundido com uma decisão administrativa ex officio, tardiamente, com eficácia retroativa, com aplicação da prescrição quinquenal sobre o fundo de direito, atualização monetária e juros de mora, pois apenas o benefício do auxílio mensal foi condicionado ao protocolo de requerimento perante o INSS - Instituto Nacional do Seguro Social, tendo como data do início desse benefício a data desse protocolo de requerimento (artigo 45 da Lei no 12.663, de 2012).

Os auxílios mensais concedidos pela referida Lei Geral da Copa aos ex-jogadores campeóes das Copas do Mundo de 1958, de 1962 e de 1970, embora constituam prestaçóes continuadas, não possuem cunho assistencialista pelo só fato de não haver previsão expressa na Constituição, visto que os benefícios assistencialistas são restritos às pessoas que estejam em elevado grau de indigência, apontadas pelo artigo 203, inciso IV, da Constituição brasileira de 1988, quais sejam: a) as pessoas portadoras de deficiência que não possuírem capacidade de trabalhar; b) os idosos que estiverem desprovidos de renda e que sejam, ademais, carentes da solidariedade familiar, situação que não lhes permite demandar o direito a alimentos na Justiça Comum, com fundamento nas regras jurídicas do Direito de Família.

Além das hipóteses constitucionalmente previstas, também são destinatários das prestaçóes assistencialistas, os membros das famílias beneficiárias do complemento da 
renda mínima familiar mensal denominado "bolsa família", que não estão em situação de indigência (abaixo da linha da miséria), mas de miserabilidade (abaixo da linha da pobreza, mas acima da linha da miséria).

Pela metodologia adotada pela legislação brasileira, no artigo $20, \S 3^{\circ}$, da LOAS Lei Orgânica da Assistência Social (Lei no 8.742, de 07/12/1993, com a redação dada pela Lei no 12.470 , de 31/08/2011), a linha da miséria corresponde ao padráo de renda mensal familiar per capita igual a $1 / 4$ (um quarto) do salário mínimo, de sorte que, quem está abaixo dela é indigente, como é o caso da pessoa portadora de deficiência e da pessoa idosa às quais se refere o caput desse artigo de lei, que lhes concede o benefício de prestação continuada instituído pelo artigo 203, inciso V, da Constituição Federal de 1988.

A Lei Geral da Copa (Lei no 12.663, de 2012), embora pressuponha a existência de ex-jogadores desprovidos de renda, pressupóe que eles tenham família, cujos membros foram investidos da condição de dependentes, no artigo 39:

"Na ocorrência de óbito do jogador, os sucessores previstos na lei civil, indicados em alvará judicial expedido a requerimento dos interessados, independentemente de inventário ou arrolamento, poder-se-ão habilitar para receber os valores proporcionais a sua cota-parte" (BRASIL, Lei ${ }^{\circ}$ $12.663,2012$, art. 39).

A remissão expressa do artigo 39 da Lei no 12.663, de 2012, aos sucessores previstos na lei civil em nada altera a definição legal de dependente de primeira classe contida no artigo 16, inciso I, do Regulamento da Previdência Social (Decreto no 3.048, de 06/05/1999), apenas substitui a prova da condição de dependente pela via da jurisdição administrativa interna do INSS (segundo o rol das provas pré-constituídas extrajudicialmente do artigo 22 do mesmo Regulamento) pela prova documental pré-constituída judicialmente (o alvará judicial), ao mesmo tempo em que exclui a existência de dependentes da segunda classe (os pais) e da terceira classe (os irmãos).

Se a Lei $n^{\circ} 12.663$, de 2012, pressupóe a existência de familiares, isso afasta a possibilidade de o ex-jogador de futebol estar numa condição de indigência que o impeça de ter a sua manutenção provida pela sua família, conforme a exigência expressa contida no artigo 203, inciso V, da Constituição brasileira de 1988.

Sendo a ex-atleta olímpica Laís da Silva Souza, jovem e solteira, ao tempo da verificação do sinistro, a Lei no 13.087 , de 2015 , dá outra solução no $\$ 1^{\circ}$, do artigo $1^{\circ}$, onde pressupóe a ausência de dependentes, qualquer que seja a classe, estatuindo que a pensão especial não será transmitida a herdeiros, de sorte que se ela vier a tê-los no futuro, não usufruirão do benefício.

O benefício mensal não-contributivo concedido pela Lei no 12.663 , de 2012, se reveste da natureza jurídica de uma aposentadoria premial (se usufruído diretamente pelo 
ex-jogador de futebol), ou da natureza jurídica de pensão premial (se usufruído pelos dependentes do ex-jogador de futebol já falecido).

No caso do benefício mensal não-contributivo concedido pela Lei no 13.087 , de 2015, à ex-atleta olímpica Laís da Silva Souza, assume a natureza jurídica exclusiva de aposentadoria (aposentadoria premial), não obstante o rótulo de pensão que lhe foi atribuída.

\subsection{Elementos Subjetivos}

Do ponto de vista subjetivo, qual teria sido a atitude altruísta do legislador ao conceder esses prêmios em dinheiro e esses auxílios mensais vitalícios aos ex-jogadores de futebol e à ex-atleta olímpica. Eis um questionamento que náo pode passar despercebido.

Dentre as possibilidades, está o fundamento utilizado pela mídia, no sentido de que o legislador teria pressuposto na promulgação do Capítulo IX ("Disposiçóes Permanentes") da Lei Geral da Copa (Lei no 12.663, de 05/06/2012), que nos anos de 1958, de 1962 e de 1970, o futebol brasileiro não estava profissionalizado e, portanto, alguns dos ex-integrantes da Seleção Brasileira não teriam conseguido ganhar fortunas, em comparação com os jogadores famosos de algumas décadas para cá, que ganharam muito dinheiro na fase do futebol-empresa, e que, por isso, ficaram privados de terem uma vida digna na ociosidade, após o afastamento da atividade desportiva. Efetivamente, foram poucos os ex-jogadores da Seleção Brasileira naquelas ocasióes que se deram bem profissionalmente e ficaram ricos o suficiente para não precisar das benesses concedidas pela Lei Geral da Copa, a exemplo de Pelé. É uma interpretação que pode ser extraída claramente do texto da Lei Geral da Copa, posto que ela não concedeu os benefícios indiscriminadamente a todos os ex-jogadores, pois estabeleceu, de forma expressa e clara, no artigo 37, inciso II, que o auxílio especial mensal será concedido "para jogadores sem recursos ou com recursos limitados”, assim como no artigo 42, caput, delimitou o valor desse auxílio especial mensal como renda de complementação de outra renda mensal do beneficiário (a média mensal [1/12 avos] do valor total dos rendimentos tributáveis, sujeitos a tributação exclusiva ou definitiva, não tributáveis e isentos informados na Declaração de Ajuste Anual do Imposto sobre a Renda da Pessoa Física, conforme definição do parágrafo único), até o limite do "valor máximo de benefícios do Regime Geral de Previdência Social".

O fundamento subjetivo da concessão dos benefícios não-contributivos aos ex-jogadores de futebol difere do fundamento subjetivo da mesma concessão feita à ex-atleta olímpica, não apenas porque se tratam de dois fatos históricos de muito distanciados no tempo e no espaço, e ocorridos em circunstâncias diferentes, que conduziram a condicionamentos legais igualmente distintos. 
O estado de necessidade está pressuposto na Lei Geral da Copa, e reconhecido como constitucional pelo Excelso Supremo Tribunal Federal como sendo necessidade de cunho assistencialista.

O estado de necessidade também está pressuposto na lei que concedeu benefícios de mesma natureza à ex-atleta olímpica Laís da Silva Souza, embora em momento algum a Lei $n^{\circ} 13.087$, de 2015, tenha condicionado a concessão do benefício à comprovação da inexistência de renda pela sua beneficiária, ou tenha aventado a possibilidade de ela ter a sua manutenção provida pela família (exigências feitas expressamente pelo artigo 203, inciso V, da Constituição da República, de 1988).

Apesar da diversidade de circunstâncias, há algo em comum nas duas leis, que é um altruísmo espontâneo da União, que atende aos princípios fundamentais da República Federativa do Brasil, proclamados no artigo $1^{\circ}$, incisos II (cidadania), III (dignidade da pessoa humana) e IV (valor social do trabalho), da Constituição brasileira de 1988.

Trata-se do pressuposto da existência de uma solidariedade social inclusiva muito especial, revestida de caráter não-contributivo e premial, para quem se destacou socialmente pelo seu trabalho, e que configura uma solidariedade social meritória.

\section{A Solidariedade Social Meritória como Atributo de Cidadania e Garantia de Proteção Social Implícita da Constituição}

Diversamente da solidariedade social caritativa pressuposta no artigo 203, inciso V, da Constituição da República, de 1988, que alberga um altruísmo de compaixão para com quem seja absolutamente incapaz de trabalhar (as pessoas portadoras de deficiência), ou que não têm mais a capacidade de retornar ao Mercado de Trabalho, por terem perdido a capacidade vital ou intelectual para o trabalho (os idosos), as Leis no 12.663, de 2012, e no 13.087, de 2015, albergam um altruísmo meritório, decorrente do prestígio social adquirido pelo seu destinatário ao tempo em que teve a capacidade de trabalhar, por isso tendo alcançado fama e glória pessoal que projetaram o orgulho da cidadania brasileira, tornando-se heróis nacionais.

Náo encontramos essa solidariedade social meritória estampada no texto da Constituição brasileira de 1988, porquanto nem todo princípio jurídico está escrito, como regra, no texto constitucional, razão pela qual a "cláusula aberta" da mesma Constituição estatui, no seu artigo $5^{\circ}, \$ 2^{\circ}$, que "os direitos e garantias expressos nesta Constituição não excluem outros decorrentes do regime e dos princípios por ela adotados, ou dos tratados internacionais em que a República Federativa do Brasil seja parte".

O curioso é que temos expressamente previstos nos incisos II (cidadania), III (dignidade da pessoa humana) e IV (valor social do trabalho), do artigo $1^{\circ}$ da Constituiçáo 
brasileira de 1988, princípios jurídicos fundamentais de organização do Estado, que são inerentes aos direitos sociais de primeira geraçâo (garantias de prestaçóes negativas do Estado, mero respeito àquilo que os indivíduos e as coletividades já possuem), que isoladamente nada sugerem a respeito dos direitos sociais de segunda geração (garantias de prestaçôes positivas do Estado, restritivamente delimitado pelo Sistema da Seguridade Social), mas basta considerar que, aquilo que a Constituição impóe ao Estado, pode ser espontaneamente assumido por ele, de ofício, de sorte que a articulação dos três valores fundamentais em referência faz emergir o fundamento de um poder administrativo que encontra respaldo constitucional, até mesmo antes do advento do Movimento Constitucionalista, calcado nas práticas administrativas medievais do antigo regime senhorial português.

Portanto, o próprio Estado é agente jurígeno de direitos sociais, que tanto pode contemplar um indivíduo (como a ex-atleta olímpica Laís da Silva Souza) ou uma coletividade (aquela restritivamente formada pelos ex-jogadores de futebol campeóes das Copas do Mundo de 1958, de 1962 e de 1970).

Desta forma, até mesmo os princípios jurídicos de organização do Estado, que são indiscutivelmente inerentes ao regime adota pela Constituição brasileira de 1988, assim como aqueles princípios herdados das constituiçôes anteriores e do regime senhorial medieval português, que consolidaram práticas de políticas públicas nos governos anteriores afirmam-se como método histórico da interpretação constitucional.

A Constituição brasileira de 1988, embora seja uma "constituição cidadâ” e contenha várias disposiçôes que afirmem a solidariedade, não a proclama claramente como um princípio jurídico geral, como o faz a Constituiçấo Francesa, no local mais nobre de uma constituição, que é o preâmbulo.

Acreditamos que o legislador constituinte tenha se esforçado para se fazer entendido no preâmbulo da Constituiçấo brasileira promulgada em 1988, no sentido de que estaria proclamando o princípio da solidariedade social, que é o mais abrangente de todos os altruísmos, porém foi prolixo, misturou valores sociais distintos, e até contraditórios, para, ao final, invocar o altruísmo divino ("sob a proteção de Deus"), que é a último altruísmo com o qual os indivíduos e os grupos podem contar (a célebre "providência divina") quando o Estado e a sociedade falharem como instituiçóes de proteção social.

Portanto, o princípio jurídico geral da solidariedade social está apenas implícito no preâmbulo da Constituição brasileira de 1988, na longa construção gramatical "a igualdade e a justiça como valores supremos de uma sociedade fraterna, pluralista e sem preconceitos, fundada na harmonia social e comprometida, na ordem interna e internacional, com a solução pacifica das controvérsias".

A fraternidade é um valor diferente da solidariedade, como deixa patente o slogan adotado pelos revolucionários na Revoluçáo Francesa de 1789: "Liberté, égalité et fraternitê". 
Etimologicamente, fraternidade significa parentesco de irmáos; irmandade; amor ao próximo; fraternização; união ou convivência como irmãos, harmonia, paz e concórdia, ao passo que, do ponto de vista jurídico significa um tipo específico de altruísmo restritivo, que aplica apenas aos iguais, classificado como solidariedade classista. Até mesmo do ponto de vista histórico, o assistencialismo social que vigia na França ao tempo da Revolução Francesa se restringia às ações de proteção social desenvolvidas no âmbito interno das Irmandades Religiosas e das Confrarias, que praticavam a solidariedade entre irmáos e confrades. As confrarias eram associaçóes fechadas, que tinham como associados apenas as pessoas de mesma condição social, ao passo que as irmandades religiosas eram abertas à participação de pessoas oriundas das classes sociais as mais diversas, ainda assim praticavam uma solidariedade restrita aos irmãos, ou que, eventualmente, poderia ser estendida a outras pessoas não-irmãs, acobertando um falso altruísmo, que acobertava uma intenção da auto-promoção social de certos irmãos (TAVARES, 1989, p. 82/84). A solidariedade social no sentido da definiçáo jurídica surgiu somente após a Revolução Industrial, mais precisamente com a promulgação da lei alemã de 1883 que instituiu o seguro obrigatório contra os acidentes do trabalho. Desta forma, a expressão "sociedade fraterna" contida no preâmbulo da Constituição brasileira de 1988 remete para idéia de uma sociedade constituída por iguais, desprovida de classes sociais, o que é utópico, mesmo que o legislador constituinte a tenha adjetivado de "pluralista", pois, do ponto de vista sociológico, uma sociedade pluralista é uma sociedade constituída por povos de origem étnica, cultural e religiosa diversificada, o que já é uma característica da sociedade brasileira, como realidade social.

Sem que haja a afirmação do gênero solidariedade social como princípio constitucional, a nossa Constituição também carece da explicitação das diversas espécies e subespécies de solidariedade, muito embora tenha feito algumas poucas referências explícitas quanto à solidariedade social compulsória (artigo $3^{\circ}$, inciso I) e à solidariedade social comunitária latino-americana (artigo $4^{\circ}$, parágrafo único).

Existem várias espécies de solidariedade, ou seja, diferentes formas de manifestação do altruísmo, com significados e extensão distintos, mais amplos ou mais restritos, quais sejam: a) a solidariedade familiar; b) a solidariedade coletiva (ou classista); e, d) a solidariedade social, que se subdivide em seis subespécies: d.1) a solidariedade social espontânea; d.2) a solidariedade social compulsória; d.3) a solidariedade social por nacionalidade, d.4) a solidariedade social internacional, d.5) a solidariedade social comunitária, e, d.6) a solidariedade social meritória.

\subsection{A Solidariedade Familiar}

A solidariedade familiar é a mais elementar de todas as espécies de solidariedade, que se traduz no Direito de Família como dever de "mútua assistência" dos cônjuges 
no casamento (artigo 1566, inciso III, do Código Civil Brasileiro de 2002), sendo-lhes imposto por lei a responsabilidade jurídica pelos encargos da família (artigo 1.565, caput, da mesma lei civil).

No Serviço Social essa solidariedade já virou um slogan: "a familia é, sempre foi e sempre será, a mais antiga, a mais eficiente e a mais insubstituivel instituiçâo de assistência social'.

A família é considerada pelos sociólogos como a "sociedade mínima”, porque ser o único grupo social que se constitui a partir de apenas duas pessoas (um homem e uma mulher) e, posteriormente, se expande com a superveniência dos filhos, dos netos, dos bisnetos e demais geraçóes do mesmo tronco familiar.

Como a mais importante característica da família é a reprodução da espécie humana, só pode ser constituída por um homem e uma mulher, razão pela qual a jurisprudência trabalhista construiu a categoria das "entidades equiparadas à família”, para fins de atribuição da responsabilidade trabalhista aos membros de certas pequenas comunidades que assumem atitudes e responsabilidades próprias da família, sem ser família, tais como: a) as repúblicas de estudantes; b) as repúblicas de solteiros, e, c) as unióes gay.

Em todas as espécies de "entidades equiparadas à família" reconhecidas pela jurisprudência trabalhista, há uma comunhão de interesses de pessoas que vivem debaixo do mesmo teto, dividindo os trabalhos e as despesas domésticas, dentre elas, eventualmente, encargos trabalhistas e previdenciários decorrentes da contratação de empregados domésticos.

\subsection{A Solidariedade Coletiva (ou Classista)}

A solidariedade coletiva também é elementar, embora diga respeito a um grupo social de maior dimensão, se comparado com a família, e diz respeito ao sentimento de altruísmo que é comum aos membros de uma comunidade de pessoas, que é unida por um objetivo comum.

Esse sentimento altruísta é inerente ao associativismo humano, e corresponde a um sentimento de pertinência, de inserção, dentro de uma classe social, daí também ser conhecido como solidariedade classista, quando está relacionada com o direito do trabalho. Tanto pode dizer respeito à classe dos empregados, como à classe dos empregadores, conforme o enquadramento que se deva dar no âmbito da organização sindical. Embora normalmente se refira ao sentimento de solidariedade que une os trabalhadores que integram uma mesma profissão, ela também se refere aos trabalhadores autônomos e aos profissionais liberais que estejam submetidos à inscrição e à fiscalizalização dos órgãos regulamentadores e fiscalizadores das profissôes (por exemplo, a Ordem dos Advogados do Brasil, o Conselho Regional de Engenharia e Agrimensura, o Conselho Regional de 
Medicina, etc.). A solidariedade classista surgiu nos primórdios da Civilização e foi o elemento subjetivo que uniu os trabalhadores nas diversas instituiçóes sociais que surgiram ao longo da história, tais como a hélade e as hetérias na Grécia, os colégios em Roma, as corporaçóes-de-ofício e as guildas na Europa medieval.

Essa solidariedade coletiva congrega os interesses dos grupos sociais, que são pequenas coletividades, cujos interesses sociais, econômicos, políticos e jurídicos são interesses coletivos em sentido estrito.

Essa solidariedade coletiva foi importante nos primórdios do surgimento da previdência, quando se encontrava no seu estágio de desenvolvimento conhecido como "previdência coletiva”, que reunia as iniciativas de proteção social implementadas pelas empresas e pelas associaçóes de trabalhadores (DURAND, 1953), e, na atualidade, dá fundamento à previdência complementar e aos regimes patronais de complementaçáo de aposentadoria.

\subsection{A Solidariedade Social}

A solidariedade social corresponde ao tipo mais amplo de solidariedade, por isso se ramifica por níveis de interesses sociais, econômicos, políticos e jurídicos distintos, cobrindo um leque de circunstâncias que abrangem os interesses difusos e os interesses coletivos em sentido amplo, independente do local aonde possam se manifestar, razão pela qual transborda os limites do território onde vive a sociedade, pois além de sustentar açóes de proteção social no plano jurídico-social nacional, também atua nos planos jurídico-sociais comunitário e internacional.

\subsubsection{A Solidariedade Social Espontânea}

A solidariedade social espontânea só se manifesta eventualmente, por ocasião da ocorrência de grandes desastres ou catástrofes com vítimas e desabrigados, a exemplo dos terremotos, dos tsunamis e das enchentes, que são ocasiôes nas quais a sociedade local, a sociedade comunitária e a sociedade internacional, assim como os governos, os organismos internacionais e as organizaçóes não governamentais praticam açóes de ajuda humanitária para minimizar as perdas, salvar vidas e ajudar as vítimas e os desabrigados.

Nela se manifesta um altruísmo universal que, ao menos em princípio, é despojado de segundas intençóes, porque é deflagrada pela dor e pelo desespero das comunidades atingidas pelas catástrofes, e se caracteriza, verdadeiramente, por uma ajuda humanitária.

Salvo nos casos em que os governos reservem alguma verba orçamentária para ajudas humanitárias, ou nos casos em que os organismos internacionais e as organizaçóes não governamentais arrecadem e mantenham recursos financeiros para cobrir os custos de suas 
açóes humanitárias, ela não conta com um provisionamento prévio, e vive, portanto, das doaçóes em geral, tais como as doaçôes de roupas, de alimentos, de colchôes, de barracas, de água potável, de alimentos, de produtos higiênicos ou mesmo de doaçóes em dinheiro.

\subsubsection{A Solidariedade Social Compulsória}

A solidariedade social compulsória corresponde a um altruísmo imposto por lei, constituindo um objetivo do Estado, tal como está proclamado no artigo $3^{\circ}$, inciso I, da Constituição brasileira de 1988 .

A solidariedade social compulsória, portanto, se afasta do altruísmo espontâneo para se constituir num altruísmo construído pelas regras do direito, sob a administração do Estado.

Esse tipo de solidariedade é que atribui a característica da vinculação obrigatória dos segurados trabalhadores ativos aos regimes de previdência social, conforme exigência expressa contida nos artigos 201, caput ("filiação obrigatória”) e 40, caput ("solidário"), da Constituição brasileira de 1988, os obrigando a serem previdentes contra as suas vontades, pois o Estado os obriga a formar uma poupança coletiva durante a fase economicamente ativa de suas vidas, a fim de poderem contar com as prestaçóes das rendas mensais previdenciárias, se, porventura, forem acometidos por um infortúnio.

Diversamente do que ocorre com a solidariedade social espontânea, a solidariedade social compulsória não está fundamentada em doaçóes, pois é caracterizada pelo provisionamento.

O provisionamento da solidariedade social compulsória, que caracteriza a previdência social, é feito pela mais abrangente "pilastra" (ou "coluna") de sustentação financeira, de natureza tributária (BAZZANO, 1997).

No Brasil o provisionamento dos regimes de previdência social é feito pelos seus respectivos planos de custeio, que devem obedecer ao critério técnico do equilíbrio financeiro e atuarial, conforme exigência do artigo 201, caput, da constituiçáo brasileira (para o regime geral de previdência social) e do artigo 40, caput da mesma constituição (para os regimes próprios de previdência social dos servidores públicos).

A institucionalização da solidariedade social compulsória deu um grande impulso às técnicas de proteção social, porquanto, na essência, ela instituiu os direitos subjetivos públicos na área de ação da previdência social, diversamente com o que ocorria com a caridade, que, além de ser uma dádiva aleatória de minguados valores financeiros, através das esmolas, que eram insuficientes para cobrir as necessidades mensais do cidadão necessitado, o mantinha o cidadão com a auto-estima baixa, subjugando-o psiquicamente. 


\subsubsection{A Solidariedade Social por Nacionalidade}

A solidariedade social por nacionalidade pode se manifestar de forma espontânea ou compulsória, sendo uma manifestaçáo do sentimento de nacionalidade, ou seja, de pertinência à pátria brasileira, que deflagra um altruísmo lastreado numa igualdade de nacionalidade, e que abomina e rejeita qualquer atitude de indiferença ou de abandono em relação a um cidadão brasileiro necessitado que se encontre no exterior.

A solidariedade social por nacionalidade se manifesta espontaneamente sempre que um cidadão de nacionalidade brasileira esteja em situação de risco social fora do território nacional, envolvido em alguma catástrofe ocorrida no exterior, seja em águas internacionais (em algum naufrágio), no espaço aéreo internacional (como ocorreu na queda do aviáo da Air France no Oceano Atlântico, há poucos anos, durante uma tempestade) ou em país estrangeiro (como ocorreu com a morte de um brasileiro a caminho de Machu Pichu, também recentemente).

Mas, o que é mais comum é a solidariedade social por nacionalidade se manifestar de forma compulsória, para também impor ao cidadão brasileiro que resida, temporária ou permanentemente, no exterior, o mesmo dever de agir de forma previdente em relaçáo aos riscos sociais atuais e futuros, inscrevendo-o obrigatoriamente no regime geral de previdência social aqui no Brasil.

Eventualmente, a solidariedade social por nacionalidade é estendida compulsoriamente a cidadãos estrangeiros que prestem serviços a empresas brasileiras no exterior, ou ao governo brasileiro no exterior, ou, ainda, que prestem serviços para organismos internacionais estabelecidos no território brasileiro, conforme as previsóes legais expressas das Leis brasileiras no 8.212 (Lei do Plano de Custeio da Seguridade Social) e no 8.213 (Lei do Plano de Benefícios da Previdência Social), ambas de 24/07/1991, e o Decreto no 3.048 (Regulamento da Previdência Social), de 06/05/1999.

Trata-se de uma modalidade de solidariedade social que é regida por uma Convenção Internacional, a de número 102, de 1952, da OIT - Organização Internacional do Trabalho, que é conhecida como "norma mínima de previdência".

A referida Convenção no 102 , de 1952, da OIT, proclama um princípio jurídico de previdência social internacional, que é o princípio da não dupla vinculação obrigatória a mais de um sistema de proteção social, uma vez que, primeiramente, não haveria necessidade de o cidadão receber ações protetivas provenientes de mais de um sistema de proteção social, segundo, porque, se já é dispendioso para o trabalhador contribuir para um sistema de proteção social, seria duplamente dispendioso para ele contribuir para mais de um sistema de proteção social, ficando privado de atender às suas necessidades existenciais no presente, a pretexto de obter dupla (ou mais) proteção no futuro. 
Esse princípio da não dupla vinculação obrigatória a mais de um sistema de proteção social, seja ele de previdência social ou de seguridade social, é causa excludente da vinculação compulsória dos segurados obrigatórios empregados descritos no artigo 9o, inciso I, alíneas "e", "g" e "q", do Decreto no 3.048, de 1999.

Desta forma, estão excluídos da vinculação obrigatória como segurados da previdência social brasileira, os empregados das missôes diplomáticas ou das repartiçóes consulares de carreira estrangeira, que sejam estrangeiros sem residência permanente no Brasil ou que sejam brasileiros sem residência no Brasil, desde que amparado pela legislação do país da respectiva missão diplomática ou da repartição consular (artigo 90, inciso I, alínea "e", do Decreto no 3.048, de 1999). Está implícito em tal preceito de lei que os empregados que sejam cidadãos da mesma nacionalidade das missóes diplomáticas ou das repartiçóes consulares de carreira estrangeira estabelecidas no Brasil não estão vinculados compulsoriamente à previdência social brasileira, independente de haver ou não uma legislação previdenciária que os ampare no seu país de origem, já que a responsabilidade pelo amparo social é sempre do país empregador do qual obteve a sua nacionalidade.

Também estão excluídos da vinculação obrigatória como segurados da previdência social brasileira os brasileiros civis que trabalham para a União no exterior, em organismos oficiais internacionais dos quais o Brasil seja membro efetivo, ainda que lá domiciliado e contratado, quando forem amparados por regime próprio de previdência social instituído pela lei do país da localidade da prestação desses serviços (artigo 9º, inciso I, alínea "f", do Decreto no 3.048, de 1999).

Igualmente, estão excluídos da vinculação obrigatória como segurados da previdência social brasileira os estrangeiros contratados pela União para prestar serviços no exterior na condição de "auxiliares locais", de conformidade com os artigos 56 e 57 da Lei no 11.440 , de 29/12/2006, "desde que, em razão de proibição legal, náo possa filiar-se ao sistema previdenciário local" (artigo 9o, inciso I, alínea "g", do Decreto no 3.048, de 1999). Essa solidariedade social por nacionalidade do estrangeiro é obtida por extensão da responsabilidade que a União tem em relação ao brasileiro civil contratado para trabalhar nas mesmas repartiçóes governamentais brasileiras situadas no exterior, à qual se soma a sua responsabilidade jurídica trabalhista, visto que a mencionada Lei no 11.440 , de 2006, rege um regime próprio de trabalho, diferente do regime estatutário do servidor público efetivo, do regime estatutário do empregado público e do regime estatutário de trabalho temporário para o Poder Público, que regem, dentro do território brasileiro, as relaçóes entre a Administração Pública e o servidor público, também não sendo um regime jurídico de trabalho que integre o sistema jurídico celetista.

Por derradeiro, também estão excluídos da vinculação obrigatória como segurados da previdência social brasileira os empregados de organismos oficiais internacionais ou 
estrangeiros estabelecidos no Brasil, que não estejam cobertos por regime próprio de previdência social (artigo 9o, inciso I, alínea “q”, do Decreto no 3.048, de 1999), qual seja um regime de previdência social estrangeiro, que tenha sido instituído pelo país da origem da sua nacionalidade ou segundo o critério geral de vinculação previdenciária estabelecido pela Convenção no 102, de 1952, da OIT.

\subsubsection{A Solidariedade Social Internacional}

A solidariedade social internacional, ao contrário do que se diz em relação à solidariedade social por nacionalidade, está fundamentada num altruísmo em relação aos cidadãos que não são brasileiros, por terem nacionalidade estrangeira.

Ela não se confunde com a solidariedade social espontânea da sociedade civil, que não conhece fronteiras e é descompromissada, mas pode ser assumida espontaneamente pelo Estado, para resolver situaçóes jurídicas que resultem da trans-nacionalização do trabalho, desta forma assumindo responsabilidade jurídica pela proteção social dos estrangeiros que prestam serviços para o Brasil no exterior ou a proteçáo social dos estrangeiros que imigraram para o Brasil, aqui estabelecendo residência permanente.

Ela é precipuamente uma solidariedade social compulsória, construída pela União em face de uma sociedade estrangeira, à qual não lhe é possível impor qualquer compulsoriedade através das leis brasileiras, muito menos para construí-la da forma que o legislador constituinte brasileiro pretendeu em relação à sociedade brasileira no artigo 30, inciso I, da Constituição brasileira de 1988.

A solidariedade social internacional decorre das relaçóes internacionais estabelecidas pelo Governo brasileiro com outros países, e são regidas pelos princípios constitucionais dispostos no artigo $4^{\circ}$ da Constituição brasileira de 1988 , dentre os quais se destaca o princípio da cooperaçáo entre os povos para o progresso da humanidade.

Sendo a proteção social um direito humano, de conteúdo material, se insere, perfeitamente, como objeto juridicamente tutelado por esse princípio constitucional, desde que haja um compromisso de cooperação estabelecido por tratados e convençóes internacionais, ou acordos bilaterais ou pluripartites de cooperação entre países.

Desta forma, a solidariedade social internacional tem como ponto de partida a Convenção no 102, de 1952, da OIT - Organização Internacional do Trabalho, que estabelece critérios técnicos e atuariais para a definição do que seja um sistema de proteção social, para possibilitar o intercâmbio da proteção social entre sistemas de previdência social estrangeiros, exigindo como benefícios mínimos a instituição de ao menos um tipo de aposentadoria e uma pensão, assim como a assistência médica mínima aos segurados. 
Isto posto, se tornou possível a celebração de acordos bilaterais entre os países, para possibilitar o atendimento dos seus nacionais em solo estrangeiro, com a correspondente compensação financeira ao final do exercício fiscal de cada ano.

O Brasil mantém vários acordos bilaterais de cooperação em matéria previdenciária com os vários países para os quais os brasileiros se deslocam com muita freqüência, praticamente com todos os países europeus, com todos os países da América do Sul, da América Central e da América do Norte, com o Japão e com alguns outros países asiáticos e africanos.

O Brasil também celebrou um acordo tripartite com a Argentina e o Paraguai, para possibilitar a contagem recíproca de tempo de serviço prestado no Brasil pelos argentinos e paraguaios ou a contagem recíproca de tempo de serviço prestado pelos brasileiros na Argentina ou no Paraguai, para que possam obter os benefícios previdenciários em qualquer desses países nos quais pretendam se radicar definitivamente após a aposentadoria.

\subsubsection{A Solidariedade Social Comunitária}

A solidariedade social comunitária é da mesma espécie da solidariedade social internacional, porém tendo um âmbito de atuação restrito ao território dos países que integram uma comunidade econômica (v.g., como é o caso da União Européia) ou uma comunidade cultural (como é o caso da Comunidade Lusófona, dos países de língua portuguesa).

A solidariedade social comunitária está presente nas Diretivas que regem a União Européia, estabelecendo regras de cooperação, de conteúdos os mais variados, notadamente em matéria trabalhista e de seguridade social, para resolver as mais variadas situaçóes jurídicas que decorrem da trans-nacionalização do trabalho dentro do espaço interno da União Européia.

A solidariedade social comunitária está expressamente prevista no parágrafo único do artigo $4^{\circ}$ da Constituição brasileira de 1988, no qual o legislador constituinte estabeleceu o compromisso permanente do Brasil com a integração latino-americana, com visos à formação de uma comunidade própria:

"A República Federativa do Brasil buscará a integração econômica, política, social e cultural dos povos da América Latina, visando a formação de uma comunidade latino-americana de naçóes" (BRASIL, CF, 1988, art. 4).

Nas comunidades econômicas e culturais, os cidadãos dos países que as integram adquirem uma nacionalidade acessória, pois além da nacionalidade conferida por seus 
países de origem, passam a usufruir da cidadania comunitária, da qual decorre um altruísmo de nivelamento.

\subsubsection{A Solidariedade Social Meritória}

A solidariedade social meritória é uma espécie de solidariedade social que não é compulsória, mas também não é espontânea, pois decorre de um altruísmo condicionado ao mérito de certos cidadáos nacionais.

A solidariedade social meritória decorre do altruísmo do Estado, e não do altruísmo da sociedade, estando historicamente fundamentado no "dever régio de premiar", que se estabeleceu como princípio jurídico no antigo regime senhorial medieval português.

O dever de premiar ou galardoar era uma componente indissociável da prática genérica da Justiça, que consistia num dos atributos régios fundamentais, de sorte que os reis, mais do que ter o direito de distribuir mercês, tinham o dever de fazê-lo, premiando os serviços dos seus vassalos e fiéis e assegurando-lhes a condição e o estado que os seus deveres exigiam (SALDANHA, 1991, p. 61).

Desta forma, os méritos do cidadão o habilitam a receber um amparo social específico por parte do Estado e às custas do erário público, quando esse cidadão não puder obter o amparo social de que necessita dentro de um regime de previdência social, revestindose, portanto, de um caráter premial.

Não se tratam de benefícios meramente assistenciais, que somente são assegurados e concedidos aos cidadãos portadores de deficiência e aos idosos em elevado grau de indigência, "que comprove não possuir meios de prover à própria manutenção ou de tê-la provida por sua família”, como é o caso da renda mensal instituída pelo artigo 203, inciso IV, da Constituição brasileira de 1988.

Também não se inserem nos planos de benefícios da previdência social, sendo, por isso, instituídos com caráter de excepcionalidade, com o rótulo de aposentadorias ou de pensóes especiais, sem custeio prévio, sendo arcados os seus custos financeiros pelo Tesouro Nacional.

O que justifica, portanto, a concessão desses benefícios de prestação única ou de prestação continuada, sob a forma de aposentadorias ou de pensóes especiais premiais, é o mérito decorrente do trabalho durante o tempo em que os seus beneficiários eram economicamente ativos, que lhes conferiu prestígio social, transformando-os em heróis nacionais.

No caso dos ex-jogadores da Seleção Brasileira de futebol campeóes das Copas do Mundo de 1958, de 1962 e de 1970, eles se tornaram heróis não apenas dos brasileiros, mas também heróis de várias geraçóes de cidadãos estrangeiros amantes do Futebol, a 
ponto de terem consagrado o jogador brasileiro "Pelé" (alcunha do cidadáo Edson Arantes do Nascimento) como o "Rei do Futebol".

No caso específico da atleta olímpica Laís da Silva Souza ela era uma promessa de mais medalhas olímpicas para o Brasil, além daquelas que já tinha conquistado na sua curta trajetória de glória, que foi interrompida, para sempre, pelo destino, o que não subtraiu o reconhecimento da opiniáo pública e o orgulho do povo brasileiro pelo trabalho até então por ela realizado no campo esportivo, razão pela qual a Lei no 13.087 , de 2015 , expressou esse sentimento nacional e concedeu a aposentadoria premial como reconhecimento de mérito.

\section{O Valor das Rendas Mensais Vitalícias Concedidas aos Ex-Jogadores de Futebol e à Ex-Atleta Olímpica}

Embora os benefícios não-contributivos mensais e vitalícios concedidos aos ex-jogadores de futebol e à ex-atleta olímpica tenham em comum o gênero, diferem quanto à espécie, porque, no primeiro caso, o benefício tem valor complementar (para complementar renda já existente), e, no segundo caso, o benefício tem valor integral (para substituir renda cessada).

Essa observação mais reforça o argumento de que essas rendas mensais vitalícias e não contributivas concedidas aos ex-jogadores de futebol e à ex-atleta olímpica se revestem de natureza previdenciária, e não de natureza assistencial, posto que a renda mensal vitalícia estabelecida pelo artigo 203, inciso V, da Constituição brasileira de 1988, tem valor único, e corresponde ao valor fixo de 1 (um) salário mínimo, para as pessoas portadoras e deficiência e para os idosos, assim como, no Programa Bolsa Família, o valor do benefício assistencialista é complementar de uma renda mensal que não é individual, mas familiar.

\subsection{O Valor Complementar da Renda Mensal Vitalícia Concedida aos Ex-Jogado- res de Futebol pela Lei $n^{0}$ 12.663, De 2012}

O valor do auxílio especial mensal concedido aos ex-jogadores de futebol das seleçóes campeãs das Copas Mundiais de 1958, de 1962 e de 1970, pressupóe a existência de uma renda qualquer, no sentido tributário definido pela legislação do imposto de renda, que determina a apuração de uma renda mensal inicial, correspondente a "1/12 (um doze avos) do valor total dos rendimentos tributáveis, sujeitos a tributação exclusiva ou definitiva, não tributáveis e isentos informados na respectiva Declaração de Ajuste Anual do Imposto sobre a Renda da Pessoa Física" (artigo 42, parágrafo único, da Lei no 12.663 , de 2012). 
Uma vez apurado o valor dessa renda mensal inicial, correspondente à média mensal dos ganhos tributáveis, sobre ela incidirá a complementação do seu valor "até que seja atingido o valor máximo do salário de benefício do Regime Geral de Previdência”, conforme estatuído no artigo 42, caput, da Lei no 12.663, de 2012.

Desta forma, o benefício concedido corresponde a um direito sujeito a condição suspensiva, sendo suscetível de ser adquirido apenas pelo ex-jogador de futebol campeão das Copas do Mundo de 1958, de 1962 e de 1970, ou por seus dependentes, caso essa renda mensal inicial seja menor do que o valor do limite-teto dos benefícios do Regime Geral de Previdência Social, que é regido pela Lei do Plano de Benefícios da Previdência Social (Lei no 8.213, de 24/07/1991).

\subsection{Valor Integral da Renda Mensal Vitalícia Concedida à Ex-Atleta Olímpica pela Lei no 13.087, de 2015}

Diversamente do que foi concedido aos ex-jogadores de futebol pela Lei Geral da Copa, o benefício mensal vitalício da ex-atleta olímpica Laís da Silva Souza corresponde a um valor integral, configurando um direito subjetivo público incondicionado, tendo sido fixado com base num valor único, correspondente ao valor máximo dos benefícios do regime geral de previdência social, conforme a disposição do artigo $1^{\circ}$, caput, da Lei no 13.087 , de $12 / 01 / 2015$.

$\mathrm{Na}$ data da publicação dessa lei, o valor do "limite-teto" dos benefícios previdenciários era de $\mathrm{R} \$ 4.663,75$ (quatro mil, seiscentos e sessenta e treis reais e setenta e cinco centavos).

\section{O Critério de Atualização do Valor das Rendas Mensais Vitalícias Conce- didas aos Ex-Jogadores de Futebol e à Ex-Atleta Olímpica}

Tanto a renda mensal do benefício vitalício concedido aos ex-jogadores de futebol das Seleçóes Brasileiras campeãs das Copas do Mundo de 1958, de 1962 e de 1970, como a renda mensal do benefício vitalício concedido à ex-atleta Laís da Silva Souza estáo atreladas ao valor do limite-teto dos benefícios concedidos pelo Plano de Benefícios do Regime Geral da Previdência Social, de sorte que seguem o mesmo critério de atualização estabelecido pela Lei no 8.213, de 24/07/1991, para a atualização dos benefícios previdenciários em geral, o que mais reforça o argumento de que essas rendas mensais não têm natureza jurídica assistencialista, e sim previdenciária.

A Lei no 12.663 , de 2012, não faz menção expressa ao critério de atualização do valor da renda mensal do benefício vitalício e náo-contributivo concedido aos ex-jogadores de futebol, deixando implícito que esse critério é o mesmo que deverá ser utilizado para 
o reajuste geral do valor dos benefícios previdenciários do Regime Geral de Previdência Social.

Mas a Lei no 13.087 , de 12/01/2015, deixa bem claro que, no caso da renda mensal da pensão especial premial concedida à ex-atleta olímpica Laís da Silva Souza, seu valor será atualizado pelos mesmos índices e critérios de atualização adotados para os benefícios do Regime Geral da Previdência Social (artigo $1^{\circ}, \$ 2^{\circ}$ ).

\section{A Fonte de Custeio da Rendas Mensais Vitalícias Não-Contributivas Con- cedida aos Ex-Jogadores de Futebol e à Ex-Atleta Olímpica}

A regra geral estabelecida pela Constituição da República, pela legislação infraconstitucional e pela prática administrativa da autarquia gestora da seguridade social, é a de que os benefícios de proteção social, sejam eles previdenciários ou assistenciais, concedidos fora do Sistema da Seguridade Social, e que, portanto, não poderão ser arcados pelo orçamento da seguridade social (artigo 165, $\$ 5^{\circ}$, inciso III, da Constituição brasileira de 1988), são de responsabilidade do orçamento fiscal, mais conhecido como "Tesouro Nacional" (artigo 165, $\$ 5^{\circ}$, inciso I, da mesma Constituiçáo).

Essa regra foi constitucionalizada pelo Decreto no 5 , de 19/11/1889, pelo Governo Provisório da I República, quando mandou listar os pobres, as viúvas, os inválidos, os enfermos e os desempregados que recebiam ajuda financeira mensal dada pelo Imperador deposto, D. Pedro II, e lhes assegurou a manutenção da renda mensal que recebiam, com encargo dos recursos do Tesouro Nacional, e, a partir de entáo, se tornou uma prática constitucional no Brasil.

Por se tratarem de benefícios não-contributivos, a dotação orçamentária para o seu pagamento náo pode ser proveniente do orçamento da seguridade social, devendo ser arcada pelo orçamento fiscal da União.

A Lei no 12.663, de 2012 (Lei Geral da Copa), estatui que o pagamento do prêmio em dinheiro aos ex-jogadores de futebol das Seleçôes Brasileiras campeâs de 1958, de 1962 e de 1970 será procedido com recursos orçamentários do Ministério do Esporte (artigo 40), e que o pagamento do auxílio especial mensal ser-lhes-á pago pelo INSS Instituto Nacional do Seguro Social (artigo 44, caput), com recursos provenientes do Tesouro Nacional (artigo 47, caput), repassados ao Ministério da Previdência Social (artigo 47, parágrafo único).

A seu turno, a Lei $n^{\circ} 13.087$, de 12/01/2015, estabeleceu que as despesas com o pagamento da pensão especial concedida à ex-atleta Laís da Silva Souza correrão por conta do "programa orçamentário indenizaçôes" e "das pensões especiais de responsabilidade da Uniáo" (artigo $2^{\circ}$ ), o que implica dizer que a fonte do seu custeio também é o Tesouro 
Nacional, estando implícito que o pagamento também será feito pelo INSS - Instituto Nacional do Seguro Social, em virtude da remissáo legislativa expressa aos índices e critérios de reajuste do Regime Geral de Previdência Social (artigo $2^{\circ}$ ).

\section{Conclusões}

O exame dos aspectos objetivos e subjetivos da concessão das rendas mensais vitalícias não-contributivas concedidas aos atletas de futebol da Seleção brasileira de futebol campeáo das Copas do Mundo de 1958, 1962 e 1970, pela Lei no 12.663, de 2012, assim como da concessão de vantagem equivalente à ex-atleta olímpica Laís da Silva Souza, pela Lei no 13.087 , de 12/01/2015, revela que, contrariamente à natureza jurídica assistencialista afirmada pelo Excelso Supremo Tribunal Federal, no julgamento da açáo direta de inconstitucionalidade, no processo ADI 4976, elas se revestem de natureza jurídica previdenciária.

Um exame mais meticuloso do tipo de altruísmo que levou a Uniáo a conceder esses benefícios mensais vitalícios não-contributivos revela a existência de uma solidariedade social meritória, que atende aos princípios fundamentais da República Federativa do Brasil, proclamados no artigo $1^{\circ}$, incisos II (cidadania), III (dignidade da pessoa humana) e IV (valor social do trabalho), da Constituiçáo brasileira de 1988, impondo reconhecer que o Estado também pode tomar a iniciativa de reconhecer direitos sociais náo previstos em lei e de conceder benefícios de proteção social não-contributivos na seara da solidariedade social meritória, que está condicionada ao mérito de certos cidadãos que obtiveram prestígio social durante a fase economicamente ativa da sua vida, em decorrência do trabalho que prestaram, o que confere o caráter premial a essas concessóes.

Essa solidariedade social meritória decorre do altruísmo do Estado, e não do altruísmo da sociedade, estando historicamente fundamentado no "dever régio de premiar", que se estabeleceu como princípio jurídico no antigo regime senhorial medieval português.

Embora os benefícios não-contributivos mensais e vitalícios concedidos aos ex-jogadores de futebol e à ex-atleta olímpica tenham em comum o gênero, diferem quanto à espécie, porque, no primeiro caso, o benefício tem valor complementar (para complementar renda já existente), e, no segundo caso, o benefício tem valor integral (para substituir renda cessada), o que reforça o argumento de que essas rendas mensais vitalícias e nãocontributivas concedidas aos ex-jogadores de futebol e à ex-atleta olímpica se revestem de natureza previdenciária, e não de natureza assistencial, aplicando-se-lhes os mesmos índices e critérios de atualização aplicáveis aos benefícios do Regime Geral de Previdência Social, o que, ao nosso ver, torna inquestionável a natureza jurídica previdenciária dessas aposentadorias e pensóes premiais, mensais, vitalícias e náo-contributivas rotuladas de "auxílio especial mensal" e de "pensão especial", posto que a natureza jurídica náo decorre 
da designação que se atribui à vantagem, mas do conjunto dos seus elementos característicos, que são, no caso desse estudo, evidentemente previdenciários.

\section{Referências}

BAZZANO, Claudio. La Previdenza Complementare e Integrativa; Dal primo al quarto pilastro. Milão: Cosa \& Come. 1997.

BRASIL. Constituiçáo da República Federativa do Brasil. Brasília, DF: Senado Federal. 1988.

BRASIL. Lei no 8.213, de 24 de julho de 1991. Dispóe sobre os Planos de Benefícios da Previdência Social e dá outras providências. Diário Oficial [da] República Federativa do Brasil. Brasília, DF, 25 jul. 1991.

BRASIL. Lei no 8.742, de 07 de dezembro de 1993. Dispóe sobre a organização da Assistência Social e dá outras providências. Diário Oficial [da] República Federativa do Brasil. Brasília, DF. 08 dez. 1993.

BRASIL. Decreto no 3.048, de 06 de maio de 1999. Aprova o Regulamento da Previdência Social, e dá outras providências. Diário Oficial [da] República Federativa do Brasil. Brasília, DF, 07 maio 1999.

BRASIL. Lei no 12.663, de 05/06/2012. Dispóe sobre as medidas relativas à Copa das Confederaçôes FIFA 2013, à Copa do Mundo FIFA 2014 e à Jornada Mundial da Juventude - 2013, que serão realizadas no Brasil; altera as Leis nos. 6.815, de 19 de agosto de 1980, e 10.671, de 15 de maio de 2003; e estabelece concessão de prêmio e de auxílio especial mensal aos jogadores das seleçóes campeãs do mundo em 1958, 1962 e 1970. Diário Oficial [da] República Federativa do Brasil. Brasília, DF, 06 jun. 2012.

BRASIL: Lei no 13.087 , de 12/01/2015. Concede pensão especial à atleta Laís da Silva Souza. Diário Oficial [da] República Federativa do Brasil. Brasília, DF. 13 jan. 2015.

DURAND, Paul. La Politique Contemporaine de la Sécurité Sociale. Paris: Dalloz. 1953.

SALDANHA, Antônio Vasconcelos de. As Capitanias: O Regime Senhorial na Expansão Ultramarina Portuguesa. Funchal: Centro de Estudos de História do Atlântico. 1991.

TAVARES, Maria José Pimenta Ferro. Pobreza e Morte em Portugal na Idade Média. Lisboa: Editorial Presença. 1989. 